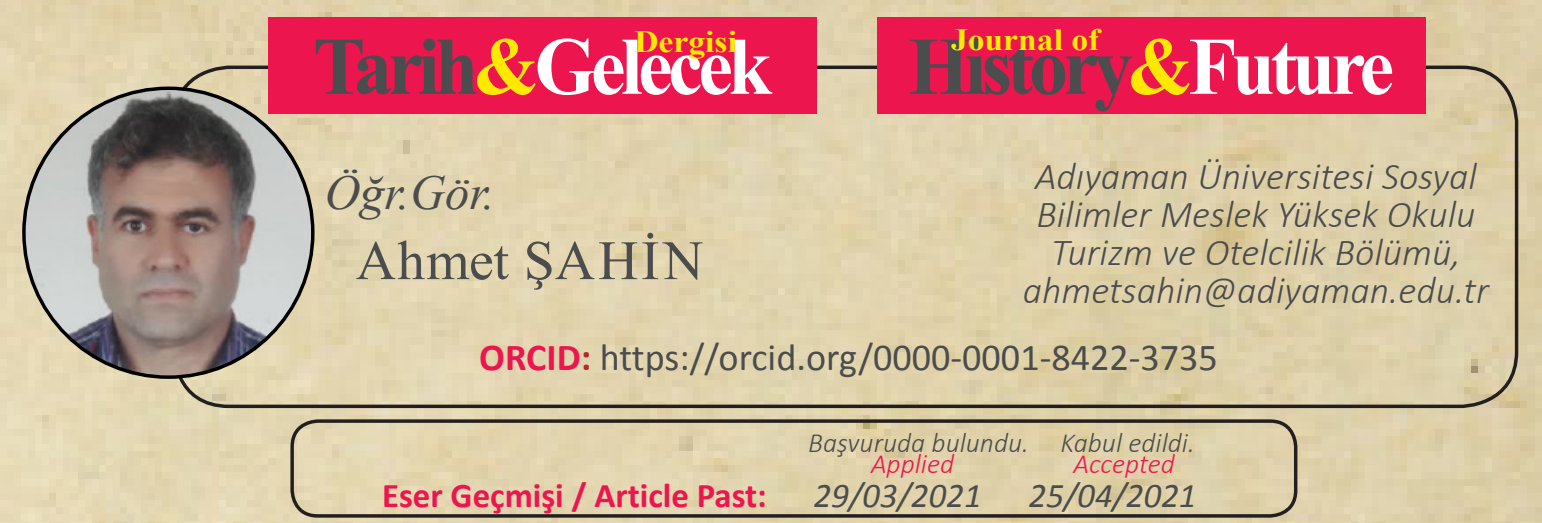

Araştırma Makalesi

DOI: http://dx.doi.org/10.21551/jhf.905558

Research Paper

Indexed by

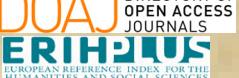

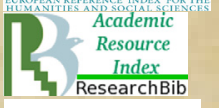

RìlSA $\mathbf{M}$

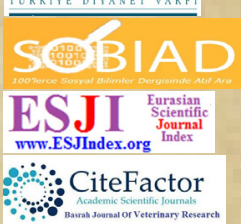

ideal

Orjinal Makale / Orginal Paper

\title{
The Criticism of Abuse of Religion in the Novel of Animal Farm by George Orwell
}

\author{
George Orwell'in Hayvan Çiftliği Romanında Din İstismart \\ Eleştirisi
}

\begin{abstract}
After Tsarist Russia had come to an end as a result of the popular uprisings in Russia in 1917 , when the First World War continued, a new state named the Union of Soviet Socialist Republics (USSR) was established by the Bolsheviks in a wide geography on the basis of communism. Before the establishment of the new state, the Russian Orthodox Church initially favoured the Tsarist Russia and made propaganda against the Bolsheviks by taking advantage of the influence of religion on the masses. After the success of the Russian Revolution, the church was purged of the state, its activities were significantly banned, and lots of clergymen were punished by being arrested, exiled, or murdered. However, shortly before the start of the Second World War, the Stalin administration had felt the need for religion and gradually allowed the activities of the church again. The fact that the previously antirevolutionary church was compatible with the new regime in line with political interests made George Orwell put the issue of religious abuse indirectly on the agenda of his novel Animal Farm.

In this study through the example of the novel Animal Farm, how the Russian Orthodox Church used first by anti-revolutionists, then by revolutionists has been examined. Then, the causes of political exploitation of religion and their consequences have been discussed.
\end{abstract}

Key words: Russian Orthodox Church, religion, abuse of religion, Bolshevik Revolution

\section{Öz}

Birinci Dünya Savaşının devam ettiği 1917 yılında Rusya'da gerçekleşen halk ayaklanmaları sonucu Çarlık Rusya'sı sona ermiş, Sovyet Sosyalist Cumhuriyetler Birliği (SSCB) adıyla Bolşevikler tarafından komünizm temelinde geniş bir coğrafyada yeni bir devlet kurulmuştur. Yeni devletin 
kuruluşundan önce Rus Ortodoks Kilisesi başlangıçta Çarlık Rusya'sından yana tavır almış, dinin halk üzerindeki etkisinden yararlanarak Bolşeviklere karşı propaganda başlatmıştır. Rus Devriminin başarılı bir şekilde gerçekleşmesinin ardından, yeni yönetim tarafından kilise devletten tasfiye edilmiş, faaliyetleri önemli ölçüde yasaklanmış, birçok din adamı tutuklanarak, sürgün edilerek ya da öldürülerek cezalandırılmıştır. Ancak İkinci Dünya Savaşının başlamasına kısa bir süre kala Stalin yönetimi dine olan ihtiyacı hissetmiş, kilisenin faaliyetlerine yeniden aşamalı bir şekilde izin vermiştir. Daha önce devrim karşıtı olan kilisenin bu kez yeni yönetimle siyasi çıkarlar doğrultusunda uyumlu olması Orwell'in romanında dinin politik çıkarlar doğrultusunda kullanılması konusunu dolaylı olarak gündemine getirmiştir.

Bu çalışmada Hayvan Çiftliği romanı örneği üzerinden Rus Ortodoks Kilisesi’nin önce devrim karşıtları tarafından daha sonra devrimciler tarafından nasıl suiistimal edildiği incelenmiş, ardından dinin politik istismarının nedenleri ve sonuçları ele alınmıştır.

Anahtar kelimeler: Rus Ortodoks kilisesi, din, din istismarı, Bolşevik Devrimi

\section{Introduction}

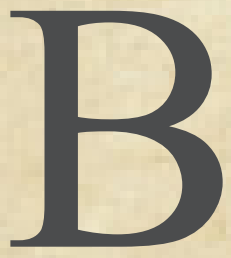

ritish author George Orwell made his novel Animal Farm published in 1945 just after the Second World War. It is a fable and satirical piece of critical writing. In this work, Orwell in his own allegorical expressions criticised the weaknesses and faults of the last Russian Tsar Nicholas II, and Joseph Stalin who remained in power until 1953.

In allegorical narratives, authors give their messages through symbols that have hidden meanings. The messages given are mostly political, religious or moral.

Allegorical expressions can also be described as symbolic expressions. A thought, concept or event corresponding to real life is represented by different people and objects. In this way, the author both concretizes an abstract and a philosophical subject and provides the reader with deeper insight.

The authors leave the discovery of the hidden messages that are underlying an event through symbols to the readers. Thus, the authors keep a distance between themselves and the readers on the subjects they discuss. For example, in this work, a group of animals led by the pigs revolted in the hope of law, justice, equality and freedom. And then, they took the management of the farm and expelled people. The secret story underlying this event is the Russian Revolution, in which each of its characters is represented differently.

In this novel, the farm represents the state. The animals represent ordinary people who are ruled. Mr Jones symbolises the last Russian Tsar Nicholas II. Among the pigs, Napoleon and Snowball symbolise Lenin and Stalin who are the pioneers of the revolution. The donkey named Boxer symbolizes the working class. The dogs symbolize law enforcement.

As for Moses the raven, it is a kind of crow whose colour is black. It is the favourite of $\mathrm{Mr}$ Jones. Despite having a good oratory ability, he is a gossip and makes a lot of empty talks. It represents the Russian Orthodox Church for its colour. 
In the novel, it is indirectly pointed out that the Russian Orthodox Church was used and abused in the Tsarist period to maintain the interests of the ruling class and to prevent the efforts of creating a new political system in accordance with the conditions of the time.

George Orwell slams the Stalin administration politically and points to the Russian Orthodox Church theologically. In general, he criticizes the oppressive and totalitarian governments and religious institutions that act according to the instructions of political authorities. If we say that the events in the novel describe only a historical period and that they have nothing to do with us, we would be deceiving ourselves. It is appreciated that sometimes special reasons lead to the emergence of general provisions.

When we look at both history and the present time, we see that the values considered sacred by religion have sometimes been abused by political opponents. Despite this, it is generally assumed that the use and manipulation of religion is a case in monarchical, theocratic regimes. Contrary to this claim, it is sometimes witnessed in secular systems too as in the Bolsheviks. Sometimes religion has been used by those who are in power and sometimes by those who struggle for power. The Tsar regime's taking advantage of religion against the political opponents who were preparing for a big revolution in 1917 and then after more than two decades, the Stalin administration's taking advantage of religion against the masses exemplify this fact.

As a matter of fact, Orwell has nothing to do with the Russian Orthodox Church. He implicitly points to the fact that all institutional/organized religions operating under the control of the political authority may cause some problems when clergymen distort the facts against ordinary people.

When the work of Animal Farm is deeply analysed, it is clearly understood under what conditions the 1917 Bolshevik Revolution took place and what social, political, economic factors led to the collapse of Tsarist Russia and paved the way for a new political order. Nonetheless, this study has been limited to the political use of religion before and after the revolution.

The importance of this issue stems from the fact that abuse of religion is one of the most complained social problems encountered in countries that have no or very little democratic culture. The main causes of this problem have been tried to be determined based on the example of Animal Farm.

Last but not least, it is considered to be important to know what historical facts correspond with the events occurring metaphorically and figuratively in the novel. We have tried to determine this through contents analysis of the relevant passages in the novel.

\section{The Role and Position of the Church on the Way to Revolution}

It is possible to investigate the role and position of the church on the way to the revolution under two main headings: pre-revolution era and post-revolution era

\section{1. Pre-revolution era}

The church stood against the revolutionary forces who wanted to put an end to the Tsarist regime. Orwell narrates the attitudes of the church against revolutionists as follows: 
"The pigs had an even harder struggle to counteract the lies put about by Moses, the tame raven. Moses, who was Mr Jone's especial pet, was a spy and a tale-bearer, but he was also a clever talker. He claimed to know of the existence of a mysterious country called Sugarcandy Mountain, to which all the animals went when they died. It was situated somewhere up in the sky, a little distance beyond the clouds, Moses said. In Sugarcandy Mountain it was Sunday seven days a week, clover was in season all the year-round, and lump sugar and linseed cake grew on the hedges. The animals hated Moses because he told tales and did no work, but some of the pigs believed in the Sugarcandy Mountain, and the pigs had to argue very hard to persuade them that there was no such place."

What is meant by Sugarcandy Mountain is Paradise ${ }^{2}$. In the Old Testament, Moses is known to be a Hebrew prophet. He helped the Israelites to get out of Egypt and led them to the Promised Land. The reason why Orwell chooses this name for the deceitful raven may be the similarities between the two promises. Prophet Moses promised a land on earth where they could live happily on the condition that they followed God's ten commandments. Moses the raven in the novel promises a place somewhere beyond the clouds up in the sky where they will no longer work and enjoy their life.

Moses the raven promises farm animals hope and reward in life after death. It also encourages the animals to give in to their fate. This is a clear reference to the influence of religious figures in society through the symbol of Moses the raven. Although he is ridiculed by the pigs, they prefer to tolerate him $^{3}$.

The church distorted religious facts. This clearly shows that religion was used as a propaganda tool in favour of the government. When religious discourses are perverted, it means that it is manipulated as a tool for abuse ${ }^{4}$.

The fact that the pigs, the leaders of the revolution, had to fight against the lies spread by Moses the raven, reveal that people are quickly fooled into religious propaganda and that it is not easy to convince them that what they hear is nothing but lies and superstitions. The reason why Moses the raven was a favourite of Mr Jones, The Russian Tsar Nicholas II, is that he had very good oratory skills and that he used this talent well against the public.

The church manipulated society's perception of heaven and distracted people's attention with a false promise of heaven so that they would not get engaged in world affairs. Because of the misuse of society's perception of heaven, the church was ridiculed by Orwell.

All the animals on the farm were deeply influenced by what Moses the raven told. This shows that it is difficult to direct ignorant masses who are easily deceived by religious dogma to the

1 George Orwell, Animal Farm (Penguin Books, 1951), 11.

2 Wanda Opalinska, Animal Farm (York Press, 2010).

3 James Inch, Communism and the Betrayal of the Revolution: A Marxist Critique of the Post-Revolutionary Manipulation of the Proletariat in Animal Farm, 2016, http://urn.kb.se/ resolve?urn=urn:nbn:se:hig:diva-23167.

4 Yusuf Batar, “'Dini” Manipülasyonlar Karşısında İmam Hatip Okullarının Misyonu', Journal of Education in Muslim Societies and Communities, 2017. 
right path. It is easy but not ethical to misguide people's emotions. What is challenging is to make the masses see the facts by encouraging them to use their minds and logic.

It should also be noted that the Russian Orthodox Church was an official institution that had operated within a legal and constitutional framework for hundreds of years. It was placed at the centre of the political system. From its foundation until its collapse Tsarist Russia had the Byzantine model in terms of its relation with religion. In the Byzantine model, religion and the clergy completely depend on the government.

When a particular religion is accepted as the state religion, clergy members of that religion are respected by society and they legitimize many decisions and actions of political powers 5 .

It is also noteworthy that when Tsarist Russia declared the Bolsheviks illegal, the church like all official institutions was expected to take a stand against them. If religious affairs and state affairs had been separated, the church would not have had to be affiliated with any political group and would not have had to take sides.

Needless to say, this is not the case Orwell implicitly criticizes. The secularization process of societies and states vary widely. Even such a process may have never started in some societies.

Orwell's main criticism is that those who have religious representation make statements contrary to what they believe. It is also not ethical for a person, group, or institution to act against their own principles, laws, and rules.

\subsection{The Purge of the Church After the Revolution}

After the great revolution had taken place in the animal farm under the leadership of Napoleon and Snowball, the management of the farm was taken over, and a new order which was completely different from the previous one was set up.

"Now, as it turned out, the Rebellion was achieved much earlier and more easily than anyone had expected........Mrs Jones looked out of the bedroom window, saw what was happening, hurriedly flung a few possessions into a carpet bag and slipped out of the farm by another day. Moses sprang off his perch and flapped after her, croaking loudly...... Jones was expelled, and the Manor Farm was theirs."

Moses the raven who previously called people to support the old regime was severely punished by the new administration for this behaviour. When the Bolsheviks seized power in 1917, they immediately started to fight against the church for the construction of a new society and adopted the removal of religious belief from all the public spheres ${ }^{6}$. For this purpose, the atheist-communist regime destroyed many churches. It arrested and killed lots of clergymen. Not only churches but hundreds of mosques and synagogues were closed or destroyed as well?.

5 H.Yunus Apaydın, Ilmihal-II-İslam ve Toplum, 21st ed., vol. II (Ankara: Türkiye Diyanet Vakfı Yayınları, 2013).

6 Anna Dickinson, 'Quantifying Religious Oppression: Russian Orthodox Church Closures and Repression of Priests 1917 $\square 41$ ', Religion, State and Society 28, no. 4 (1 December 2000): 327-35, https:// doi.org/10.1080/713694776.

7 Roger R. Reese, 'The Russian Orthodox Church and "Patriotic" Support for the Stalinist Regime during the Great Patriotic War', School of Humanities \& Social Sciences, The University of New South Wales, 
The Bolsheviks who based their ideas partly on Marxism thought that the church was reactionary. For them, it had to be purged, its influence on Russian society had to be eliminated. However, they did not have a very clear road on how to do this. Through a series of decrees issued in 1917, the church was deauthorised in some certain matters such as land, marriage, divorce, and schools. By passing the decrees in 1918, the separation of the church and the state from each other was fully realized. In addition, the assets of the church were confiscated, the chapels and schools belonging to the church were closed down. With the decrees issued in the same year, the secularization of education at all levels was ensured. These practices were followed by the arrest and murder of some clergy in the same year ${ }^{8}$.

After the death of Lenin in 1924, Stalin, who took over the administration, significantly banned religious activities in his country until the beginning of the Second World War. He made some of the churches destroyed and made some of them repurposed. Below is a list of some of the destroyed or repurposed churches:

- Cathedral Christ the Saviour

It was destroyed with explosives by the Soviet leader Joseph Stalin in $1931^{9}$.

- The Church of Saint Nicholas

This church was in Moscow and it was turned into a museum and used as a warehouse for artworks.

- Noginskteki Church

It was turned into a cinema. The dome of the church and its relics were removed so that no one would understand that it was once used as a church.

- St Isaac's Cathedral

It was the biggest church in St Petersburg. It was turned into a museum.

- St George the Victorious

This church which was located in Moscow was used as the headquarter by the secret service of the Russian state.

- Kazan Cathedral

This church was located in the Red Square. It was destroyed in 1936. In its place, a fountain and a public restroom were made.

- Moscow's Church of the Resurrection

It was turned into a gym for factory workers.

2014, https://doi.org/DOI 10.1179/0729247314Z.00000000035.

8 Scott M. Kenworthy, 'Rethinking the Russian Orthodox Church and the Bolshevik Revolution' 31, no. 1 (2018), https://doi.org/10.1080/09546545.2018.1480893.

9 'The Cathedral of Christ the Saviour of Moscow: You Will Not Believe Its Story', Russiau, 30 January 2019, https://russiau.com/cathedral-christ-saviour-moscow/. 
- The Lutheran Church of Saint Peter and St Paul

It was the biggest Lutheran Protestant Church in St Petersburg. It was turned into a storage hall and then was turned into a museum.

- Andronikov Monastery of the Saviour

It was used as a concentration camp by the Soviets for the political prisoners.

- St Nicholas Church

It was used as a factory. Metals, needles, and ammunitions were manufactured here.

- Archangel Michael Cathedral

It was used as an archive by the state for books except the Bible ${ }^{10}$

Although the number of churches closed varied according to years, it gradually intensified starting from 1917 to 1940 . Until 1939 around 200-300 churches remained open throughout the Soviet Union ${ }^{11}$. However, believers were allowed to worship in their private houses. Meanwhile, the persecution of the clergy differed from region to region too, but the maximum persecution took place in $1937^{12}$. According to Vasilyeva cited by Dickinson, on the eve of the Second World War, there were a total of 6376 clergymen left, which was less than 10 per cent of the number before the revolution.

\subsubsection{The Return of the Church to the State}

Shortly before the outbreak of the Second World War, Stalin felt that his country needed religion, so he changed his policy toward the church. The institutional existence of the churches was recognized, the clergymen were allowed to come back on the condition that they spoke in favour of the political and social realities of the Soviets ${ }^{13}$. This situation in the novel is described as follows:

"In the middle of the summer Moses the raven suddenly reappeared on the farm, after an absence of several years. He was quite unchanged, still did no work, and talked in the same strain as ever about Sugarcandy Mountain. He would perch on a stump, flap his black wings, and talk by the hour to anyone who would listen. 'Up there, comrades,' he would sit solemnly, pointing to the sky with his large beak-'up there, just on the other side of that dark cloud that you can see-there it lies. Sugarcandy Mountain, that happy country where we poor animals shall rest forever from our labours! .....Many of the animals believed him. Their lives

10 Deutsche Welle (www.dw.com), 'How Churches in the Soviet Union Were Desecrated and Repurposed | DW | 22.09.2016', DW.COM, accessed 3 February 2021, https://www.dw.com/en/how-churches-in-thesoviet-union-were-desecrated-and-repurposed/g-19565103.

11 Nathaniel Davis, 'A Long Walk to Church: A Contemporary History of Russian Orthodoxy', (Westview Press, Boulder, Co., 1995.

12 Dickinson, 'Quantifying Religious Oppression: Russian Orthodox Church Closures and Repression of Priests $1917 \square 41$ '.

13 Philip Walters, 'The Russian Orthodox Church and the Soviet State', The ANNALS of the American Academy of Political and Social Science 483, no. 1 (1 January 1986): 135-45, https://doi.org/10.1177/000 2716286483001012. 
now, they reasoned, were hungry and laborious. The pigs all declared contemptuously that his stories about Sugarvandy Mountain were lies, and yet they allowed him to remain on the farm, not working, with an allowance of a gill of beer a day."

Farm animals were deeply disappointed and they realized that the promises previously made were not kept. The owners of the new farm too realized this situation due to the growing criticism by the farm animals. The exiled raven was immediately recalled and allowed to carry out his old propaganda in favour of the owners of the farm and against the animals.

War declaration by The Nazis who ruled Germany against the Soviets made Stalin change his church policy. The most important reasons for the policy change toward the church are the idea that the belief of the people could not be eliminated while fighting against the common enemy, the idea of taking advantage of the impact of religion, and the desire to make people more loyal to the regime and the state ${ }^{14}$.

These reasons correspond with Orwell's statements above. The clergymen were again promising an eternal life in a metaphysical realm after death by telling fairy tales of Sugarcandy. Thus, they would have benefitted from the influence of faith while fighting against the enemy outside the country. Apart from this, the Stalin administration may have thought that it was nonsense to polarize people over religion. He may also have thought that it was unreasonable to divide the interior front while fighting against the common enemy. Otherwise, his country would have experienced more harm than good.

The new administration likened itself to the enemy against which it had previously fought. As a matter of fact, by acquiring the bad habits of the old regime, the new rulers of the state became the loser of the struggle, not the winner.

However, nothing changed for the people who still believed in what the clergy had told before. This clearly reveals how effective religious rhetoric was on people even after the Bolshevik revolution. As in Tsarist Russia, politicians gave priority to the influence of religion, especially while going through a difficult phase.

\section{Discussion}

Religion which is an important consideration in the lives of individuals and societies has often been subjected to abuse in many areas of life such as terrorism, politics, economy, education, and sexual life. Its consequences have always been devastating and adverse ${ }^{15}$.

The use and manipulation of religion is not only a case in monarchical, theocratic regimes. Even in the USA, which is one of the most secular countries in the world, former President Trump held up the Bible outside St. John's Church in Washington $\mathrm{DC}^{16}$ when his country was shaken by

14 Şir Muhammed Dualı, 'Siyasetin Dine Etkisi Bağlamında Stalin'in Kilise Politikaları', Cumhuriyet İlahiyat Degisi 21, no. 2 (2017).

15 Gülsüm Şimşek, Reklam Etiğinde Din İstismarı Örnek Olay Incelemesi, 2016.

16 'Bishop "Outraged” after Tear Gas Used on Crowds before Trump Church Photo Op', Bradford Telegraph and Argus, accessed 29 March 2021, https://www.thetelegraphandargus.co.uk/news/national/18489990. bishop-outraged-tear-gas-used-crowds-trump-church-photo-op/. 
a massive protest.

When it is asked why an individual or a public can easily be deceived through the abuse of religion, the first things that come to mind are the good intentions, the gullibility of the masses, not having deep knowledge, being content with a little and superficial religious knowledge, not seeking the truth, not having the ability to think critically enough.

Batar considers two major reasons for the abuse of religion. 'Firstly, one's efforts to justify their behaviour for themselves and for others. Secondly, power ambition'. He thinks that 'justification' is the major cause of the abuse ${ }^{17}$.

Whatever the reasons are, abuse of religion is only possible among ignorant people who attach importance to religious dogma ${ }^{18}$. According to Çiftçi, it is also necessary to question those who are consent to the abuse ${ }^{19}$.

It is understood that George Orwell agreed with the statement of Karl Marx who lived nearly a century ago before him. He said 'Religious misery is at the same time an expression of real misery and a protest against the real misery. Religion is the sigh of the oppressed creature, the heart of a heartless world, and the soul of the soulless conditions. It is the opium of the people. ${ }^{20}$

According to Max, religion had been used by rulers for a long time to control the social, political, and cultural behaviour of the masses $^{21}$. Regardless of the reasons, abuse of religion stems from moral decay ${ }^{22}$.

No matter for what purpose religion is abused, religion itself will suffer most from this. Apart from that, people may turn away from religion, they may have tendencies towards atheistic or agnostic currents. Religious values can be a matter of a kind of game, entertainment, and ridicule.

Without doubt, abuse of religion is the worst abuse as the number of victims is not limited to a handful of people. Since religion is the weakest point of individuals especially in societies in which religious rituals and symbols rather than the essence of religion are placed at the centre of the daily and political life, its exploitation is easy, cost-effective, and its degree of effectiveness is generally higher than expected.

It should also be born in mind that in today's societies, abuse is not limited to religion only. The word abuse, which is generally described as using somebody or something badly or wrongly, often becomes a current issue with child abuse, abuse of rights, emotional abuse, spousal abuse, elderly abuse, sexual abuse, etc. Nearly everything that is valued by people such as homeland, flag, freedom, human rights, democracy, and sexuality are more or less subjected to abuse.

17 Batar, “'Dini” Manipülasyonlar Karşısında İmam Hatip Okullarının Misyonu’, 33.

18 Durmuş Yalçın, Yaşar Akbıyık, and Gülnihal Bozkurt, Türkiye Cumhuriyeti Tarihi II (Ankara: Atatürk Araştırma Merkezi, 2011).

19 Adil Çiftçi, 'Din Istismarı: Kavramsal ve Kuramsal Bir Çalışma-Sosyolojik Bir Yaklaşım', İslamiyat III, no. III (2000).

20 Karl Marx, Hegel'in Hukuk Felsefesinin Eleştirisi, trans. Kenan Somer, 2nd ed. (Ankara: Sol Yayınları, 2009), 192.

21 Jeffrey F. Addicott, 'The Misuse of Religion in the Global War on Terrorism', Barry Law Review 7 (2006): 143.

22 Hüseyin Certel, 'Din İstismarı Üzerine', Journal of Islamic Research 22, no. 1 (2011). 
Another important point is that although Animal farm is generally interpreted as Orwell's criticism against socialism by some authors, ${ }^{23}$ this claim does not fully reflect the truth. When the novel is investigated in detail, it will be concluded that the writer, who is also a defender of socialism, criticizes not socialism, but socialists, especially Stalin who were not able to make the system work properly. As Orwell is an outspoken writer, he insists on telling what some people do not want to hear ${ }^{24}$. He also believed that totalitarian governments crushed socialism ${ }^{25}$.

On the other hand, not only the Tsarist Russia or the Soviet Union, all political regimes that tend to be totalitarian or that use religion as a tool of manipulation against the masses have indirectly been the target of Orwell's criticism.

We cannot think the opposite. Otherwise, the universal messages of the novel would be narrowed. They would have been reduced to a specific region, culture, history, political ideology, and belief. The novel would remain as a historical memory that has no validity and significance today.

The anti-revolutionary and then the pro-revolutionary position of the church undoubtedly gave harm to the role of religion in social unity and integrity. While some of the members of society sympathized with the clergymen, some hated them.

Because of these policies carried out by the Soviets against the churches, they created a perception among general public that socialism/communism was hostile to religion.

Were the churches punished for collaborating with Tsarist administration and making antipropaganda against the Bolsheviks or were they punished just because socialist orders are hostile to religion? The first possibility seems to be stronger as there is no data that theoretically suggest that socialism is the enemy of religion.

The harsh and brutal counter strike of the Bolsheviks on the church put them and the socialist ideology in a difficult situation. Their attack on religion including İslam and Judaism helped their capitalist rivals to accuse socialists of being enemies of religion in the fight against socialism all over the world.

Öztürk explains this as follows: 'Deceiving the masses by the exploitation of religion continued for centuries has led to an abnormal level of hatred against religion and clergymen. ${ }^{26}$,

Undoubtedly, the main duty of clergymen both in good times and in bad times is to make correct explanations about religion for the people they address. If they neglect this duty and make

23 Gülden Çiftci, 'Kitap İncelemesi: Animal Farm (Hayvan Çiftliği)', Journal of International Management, 2013, 2; İsmail Fidan, 'Hayvan Çiftliği', Van Yüzüncü Yll Üniversitesi İktisadi ve İdari Bilimler Fakültesi Dergisi 3, no. 6 (30 December 2018): 184-89.

24 George Orwell and Russell Baker, Animal Farm: 75th Anniversary Edition, 50th Anniversary edition (New York, NY: Signet, 2004).

25 Ma Guocheng, 'Symbolism in the Absurdity of Animal Farm', The Frontiers of Society, Science and Technology 2, no. 3 (22 May 2020), https://doi.org/10.25236/FSST.2020.020308.

26 Yaşar Nuri Öztürk, 'İnsanlık komünizmi yeniden sahneye çağıracaktır!', http://www.aydinlikgazete. com/, 2015, https://www.aydinlikgazete.com/insanlik-komunizmi-yeniden-sahneye-cagiracaktirmakale,61635.html. 
themselves used by politicians, they will fall out of the favour of the masses.

That those who are in power or those who struggle to come to power turn a blind eye to the abuse and manipulation of religious values for their own interests would harm the religion itself most. What's worse, the adverse outcomes of such a policy can be so destructive that they cannot be repaired later.

\section{Result}

In this study, the underlying causes of the abuse of religion and the consequences have been discussed in the context of the Russian Orthodox Church which was symbolised by a raven in the novel of Animal Farm.

The rhetoric, symbols, and discourse used by the church were narrated by George Orwell in the style of allegory. What the church actually communicated during the political turmoil between 1917 and 1945 can be another research subject for future studies.

First, the church was used against the revolutionists. Then, the revolutionists removed it from the state. After that, it was recalled by the revolutionists for political purposes and the unity and solidarity of society against the common enemy.

Before Bolsheviks came to power in 1917, the abuse of religion by the Tsarist rule and the manipulation of religion by the church yielded no result. Yet, after the achievement of the revolution, the policy of purging religion of life did not yield result either.

Starting from 1917 until the Second World War, the Stalin administration managed to separate religious affairs from the state affairs. He even managed to silence, oppress and crush it, going further. In spite of this, the recall of the church from the same administration reveals that religion and its values that it represents cannot be completely eliminated and excluded from life.

The use of religion can be easy and may be even profitable in the short term. However, if considered in the long run, the consequences of this policy can have devastating effects.

If religion is seen as a lifesaver in hard times and used as a tool for political gains as Nicholas II and Stalin did, it is evident that such a policy will not serve a useful purpose.

As is stated above placing religion and religious symbols or rituals at the centre of life and policy seems to be the main cause of this issue.

As a result, George Orwell put on the agenda not only the problems of his own era but also the problems that can be experienced decades later. He made us feel that similar problems would emerge at different times in other parts of the world unless lessons are taken from the past.

\section{Sources}

Addicott, Jeffrey F. 'The Misuse of Religion in the Global War on Terrorism'. Barry Law Review 7 (2006): 109.

Apaydın, H.Yunus. Ilmihal-II-İslam ve Toplum. 21st ed. Vol. II. Ankara: Türkiye Diyanet Vakfı Yayınları, 2013.

Batar, Yusuf. “"Dini” Manipülasyonlar Karşısında İmam Hatip Okullarının Misyonu'. Journal of Education in Muslim Societies and Communities, 2017. 
Bradford Telegraph and Argus. 'Bishop "Outraged” after Tear Gas Used on Crowds before Trump Church Photo Op’. Accessed 29 March 2021. https://www.thetelegraphandargus.co.uk/ news/national/18489990.bishop-outraged-tear-gas-used-crowds-trump-church-photo-op/.

Certel, Hüseyin. 'Din İstismarı Üzerine'. Journal of Islamic Research 22, no. 1 (2011).

Çiftçi, Adil. 'Din Istismarı: Kavramsal ve Kuramsal Bir Çalışma-Sosyolojik Bir Yaklaşım'. Islamiyat III, no. III (2000).

Çiftci, Gülden. 'Kitap İncelemesi: Animal Farm (Hayvan Çiftliği)'. Journal of International Management, 2013, 2.

Davis, Nathaniel. 'A Long Walk to Church: A Contemporary History of Russian Orthodoxy'. (Westview Press, Boulder, Co., 1995.

Dickinson, Anna. 'Quantifying Religious Oppression: Russian Orthodox Church Closures and Repression of Priests 1917 $\square$ 41'. Religion, State and Society 28, no. 4 (1 December 2000): 327-35. https://doi.org/10.1080/713694776.

Dualı, Şir Muhammed. 'Siyasetin Dine Etkisi Bağlamında Stalin'in Kilise Politikaları'. Cumhuriyet İlahiyat Degisi 21, no. 2 (2017).

Fidan, İsmail. 'Hayvan Çiftliği'. Van Yüzüncü Yıl Üniversitesi İktisadi ve İdari Bilimler Fakültesi Dergisi 3, no. 6 (30 December 2018): 184-89.

Guocheng, Ma. 'Symbolism in the Absurdity of Animal Farm'. The Frontiers of Society, Science and Technology 2, no. 3 (22 May 2020). https://doi.org/10.25236/FSST.2020.020308.

Inch, James. Communism and the Betrayal of the Revolution : A Marxist Critique of the Post-Revolutionary Manipulation of the Proletariat in Animal Farm, 2016. http://urn.kb.se/ resolve?urn=urn:nbn:se:hig:diva-23167.

Kenworthy, Scott M. 'Rethinking the Russian Orthodox Church and the Bolshevik Revolution' 31, no. 1 (2018). https://doi.org/10.1080/09546545.2018.1480893.

Marx, Karl. Hegel'in Hukuk Felsefesinin Eleştirisi. Translated by Kenan Somer. 2nd ed. Ankara: Sol Yayınları, 2009.

Opalinska, Wanda. Animal Farm. York Press, 2010.

Orwell, George. Animal Farm. Penguin Books, 1951.

Orwell, George, and Russell Baker. Animal Farm: 75th Anniversary Edition. 50th Anniversary edition. New York, NY: Signet, 2004.

Öztürk, Yaşar Nuri. 'İnsanlık komünizmi yeniden sahneye çağıracaktır!' http://www. aydinlikgazete.com/, 2015. https://www.aydinlikgazete.com/insanlik-komunizmi-yenidensahneye-cagiracaktir-makale,61635.html.

Reese, Roger R. "The Russian Orthodox Church and "Patriotic" Support for the Stalinist Regime during the Great Patriotic War'. School of Humanities \& Social Sciences, The University y of New South Wales, 2014. https://doi.org/DOI 10.1179/0729247314Z.00000000035.

Şimşek, Gülsüm. Reklam Etiğinde Din İstismarı Örnek Olay İncelemesi, 2016. 
Russiau. 'The Cathedral of Christ the Saviour of Moscow: You Will Not Believe Its Story', 30 January 2019. https://russiau.com/cathedral-christ-saviour-moscow/.

Walters, Philip. 'The Russian Orthodox Church and the Soviet State'. The ANNALS of the American Academy of Political and Social Science 483, no. 1 (1 January 1986): 135-45. https:// doi.org/10.1177/0002716286483001012.

Welle (www.dw.com), Deutsche. 'How Churches in the Soviet Union Were Desecrated and Repurposed | DW | 22.09.2016'. DW.COM. Accessed 3 February 2021. https://www.dw.com/en/ how-churches-in-the-soviet-union-were-desecrated-and-repurposed/g-19565103.

Yalçın, Durmuş, Yaşar Akbıyık, and Gülnihal Bozkurt. Türkiye Cumhuriyeti Tarihi II. Ankara: Atatürk Araştırma Merkezi, 2011. 